\title{
THE TT GENOTYPE OF THE MTHFR 677C $>$ T POLYMORPHISM INCREASES SUSCEPTIBILITY TO PREMATURE CORONARY ARTERY DISEASE IN INTERACTION WITH SOME OF THE TRADITIONAL RISK FACTORS
}

\author{
Beata Sarecka-Hujar', Iwona Zak², Jolanta Krauze ${ }^{3}$
}

Department of Applied Pharmacy, Medical University of Silesia, Sosnowiec, Poland ${ }^{1}$; Department of Biochemistry and Medical Genetics, Medical University of Silesia, Katowice, Poland²; The First Department of Cardiac Surgery, Medical University of Silesia, Katowice, Poland ${ }^{3}$

Summary: Background: The presence of several risk factors (genetic and non-genetic) has greater impact on the risk of premature coronary artery disease (CAD) than single risk factor. Objective: The aim of the study was to establish possible relations between genotypes and alleles of $677 \mathrm{C}>\mathrm{T}$ polymorphism of $M T H F R$ gene and some traditional risk factors e.g. elevated levels of lipid parameters and smoking in development of premature CAD. Methods: The groups comprised 152 patients with angiographically documented premature CAD (aged 42.9 \pm 5.5 ) and 121 age-matched blood donors (aged $42.3 \pm 6.5$ ) were studied. The MTHFR 677C $>$ T polymorphism was genotyped with Polymerase Chain Reaction-Restriction Fragment Length Polymorphism (PCR-RFLP) method. Results: Patients with TT genotype who simultaneously smoked had increased risk of premature CAD compared to non-smoking cases with CC genotype $(\mathrm{OR}=24.62)$. We also found that individuals with TT genotype and elevated LDL-cholesterol (LDL-chol.) level had significantly higher risk of $\mathrm{CAD}(\mathrm{OR}=9.92)$ than individuals with normal LDL-chol. level and CC genotype. Conclusions: The present study shows that simultaneous presence of MTHFR TT genotype and smoking or elevated levels of LDL-chol. influences the risk of premature $\mathrm{CAD}$. This findings give interesting contribution to gene-environment interaction problem that may have clinical implications in the future.

Key words: Coronary artery disease; Polymorphism; MTHFR; Lipids; Traditional risk factors

\section{Introduction}

Coronary artery disease has a complex etiology generated by combined effects of both, genetic and environmental factors (1). The polymorphic genes, encoding products involved in atherosclerotic process, predispose individuals to a greater or lower extent to CAD. However, traditional risk factors, such as cigarette smoking, hypercholesterolemia, hypertension and overweight, interacting with the genetic risk factors (in cumulative or synergistic ways), may increase or not the risk of the disease. It is known that interactions between genetic and environmental factors are very important in subjects with a high-risk genetic profile (2). Genetic factors have greater contribution to the development of CAD at younger age (3).

Methylenetetrahydrofolate reductase (MTHFR) catalyzes a reduction of 5,10-methylenetetrahydrofolate to 5-methyletetrahydrofolate that is the carbon donor for the remethylation of homocysteine (Hcys) to methionine (4). The $677 \mathrm{C}>\mathrm{T}$ polymorphism in the MTHFR gene influences enzyme thermolability that leads to its decreased activity and to elevated level of plasma Hcys. Since hyperhomocysteinemia causes a chronic inflammatory state it is considered to be a risk factor for CAD, stroke and thrombosis (5-7). Thus, also the $677 \mathrm{C}>\mathrm{T}$ polymorphism may be considered as a risk factor for $\operatorname{CAD}(4,8)$.

The objective of the present study was to assess possible relations between genotypes and alleles of $677 \mathrm{C}>\mathrm{T}$ polymorphism of MTHFR gene and some traditional risk factors e.g. elevated levels of lipid parameters, smoking and overweight in the development of premature CAD.

\section{Materials and methods}

\section{Patients and controls}

The study population consisted of 273 subjects, white Polish Caucasians, inhabitants of Upper Silesia region (Katowice, Poland).

Group 1 (CAD) comprised 152 unrelated patients with premature $\mathrm{CAD}$ confirmed by angiography with more than $50 \%$ diameter stenosis of at least one of the major coronary vessels (64 women and 88 men, mean age $42.9 \pm 5.5$ ).

Group 2 (Control) comprised 121 age-matched healthy blood donors with no signs of CAD in interview (19 women and 102 men, mean age $42.3 \pm 6.5$ ). 
The patients were recruited from the 1 st Clinic of Cardiology in the Silesian Center of Cardiology in Katowice during the period 2000-2004. The coronary angiography was performed by means of Judkin's method. Myocardial infarction (MI) was diagnosed according to recommendations of the Joint European Society of Cardiology/American College of Cardiology Committee (9). The exclusion criteria from the study was: clinical diagnosis of cardiomyopathy, coagulopathy, collagenoses and acute poisoning (e.g. CO, amphetamine). Individuals with chronic inflammatory or autoimmune disease and any kind of dementia were also excluded. Cardiomyopathies were detected by electrocardiogram, echocardiography and coronarography. Stroke was diagnosed by computed tomography and magnetic resonance imaging. Other diseases, including peripheral artery occlusive disease, were diagnosed on the basis of medical interview, examination and laboratory methods.

Blood donors were recruited from Regional Center of Blood Donor and Blood Treatment in Katowice. The exclusion criterion was CAD or stroke revealed in the course of family history. CAD in this case was defined through its occurrence in at least one of the parents.

The entire patients' group was characterized in respect of concomitant risk factors for atherosclerosis such as hypertension, hyperlipidemia, cigarette smoking, overweight/obesity and diabetes mellitus on the basis of medical interview according to previously described standards (10).

The study protocol was approved by the Ethics Committee of the Medical University of Silesia in Katowice and all subjects gave written informed consents.

\section{Biochemical analyses}

Antecubital venous blood was collected from each participant after an overnight fast, immediately put on ice and transferred to the laboratory for serum separation within 2 hours after being drawn. Only fresh blood serum was used in the study. The levels of lipid parameters like total cholesterol (TC), high-density lipoprotein-cholesterol (HDL-chol.) and triacylglycerols (TG) were measured using enzymatic methods (commercial Analco Kit, Warsaw, Poland). The concentration of LDL-chol. was calculated according to the Friedewald formula in subjects with levels of triacylglycerols below $4.4 \mathrm{mmol} / \mathrm{l}$ (11).

\section{Analyses of polymorphisms}

Genomic DNA was extracted from peripheral lymphocytes using commercial MasterPure genomic DNA purification kit (Epicentre Technologies; Madison, WI, USA). The $677 \mathrm{C}>\mathrm{T}$ polymorphism of MTHFR was analyzed using PCR-RFLP method. Genotyping of the MTHFR polymorphism was carried out as described previously by Frosst et al. (4), with some modification of the amplification parameters, which were as follows: 5 min of initial denaturation at $96{ }^{\circ} \mathrm{C}, 35$ cycles with $35 \mathrm{~s}$ of denaturation at $93{ }^{\circ} \mathrm{C}, 5 \mathrm{~s}$ of annealing at $60^{\circ} \mathrm{C}, 30 \mathrm{~s}$ of extension at $72^{\circ} \mathrm{C}$ and $7 \mathrm{~min}$ of final extension at $72{ }^{\circ} \mathrm{C}$. The PCR product, length 198 base pairs (bp), was digested by Hinfl restriction enzyme (Promega; Madison, WI, USA) generating fragment 198 bp for genotype CC; fragments: 198, 175 and 23 bp for genotype CT and 175, $23 \mathrm{bp}$ for genotype TT. To avoid genotyping errors all restriction analyses were done in the same conditions and with the HinfI restriction enzyme coming from the same source. The CC homozygotes were considerend as wild type genotype in the whole manuscript.

\section{Statistical analyses}

Data were analyzed using the Statistica 7.1 (STATSOFT; Statistica, Tulsa, OK, USA) and the EpiInfo 6 (Centers for Disease Control and Prevention (CDC), Atlanta, GA, USA) softwares. Normality of distribution of quantitative data was computed by Shapiro-Wilk $W$ test. The comparison of mean values of quantitative data between all study groups was made using two following tests: the Student's $t$-test was used when the distribution of some data was normal and Mann-Whitney $U$ test, when the distribution of quantitative data differed from normal distribution. Allele frequencies were assessed on the basis of the genotype distribution. Hardy-Weinberg equilibrium (HWE) in all groups was tested by a $\chi^{2}$ test. The comparisons of genotype and allele frequencies between cases and controls was also assessed with the $\chi^{2}$ test. In case of small number of subjects $(<5)$ in the analysis, the Fisher's correction was used. Statistical significance was accepted at $p<0.05$. To assess an association between alleles or genotypes and the disease odds ratios (OR) as well as their 95\% confidence interval (CI) were computed. The relationships between polymorphic variants and the disease was calculated using uni- and multivariate logistic regression analysis after adjustment for traditional risk factors, such as: smoking, elevated level of TC, LDL-chol., TG, overweight/obesity. The $6 \times 2$ table approach was used to assess the additive interactions between the genotypes and traditional risk factors. The reference category involves individuals carrying no polymorphic variant and no traditional risk factor.

\section{Results}

\section{General, biochemical and clinical characteristic of the study groups}

General characteristics and levels of biochemical parameters like TC, HDL-, LDL-chol. and TG of the study groups are shown in Table 1. Cases had significantly higher levels of TC, LDL-cholesterol and TG compared to control group. The mean body mass index (BMI) value was also greater in patients than in controls. There were greater number of smokers among patients compared to controls (58\% vs 24\%, p < 0.001, OR $=4.4895 \%$ CI 2.56-7.88). 
Tab. 1: General characteristics of the study groups

\begin{tabular}{|c|c|c|}
\hline & $\begin{array}{l}\text { Patients with premature CAD } \\
\qquad \mathrm{n}=152\end{array}$ & $\begin{array}{c}\text { Control group } \\
\mathrm{n}=121\end{array}$ \\
\hline $\operatorname{Sex}(n, \%)$ & $\begin{array}{l}+94(42.1 \%) \\
+188(57.9 \%)\end{array}$ & $\begin{array}{l}\text { ㅇ } 19(15.7 \%) \\
\text { + } 192(84.3 \%)\end{array}$ \\
\hline Age $($ mean \pm SD $)$ & $42.9 \pm 5.5$ & $42.3 \pm 6.5$ \\
\hline $\mathrm{BMI}($ mean $\pm \mathrm{SD})$ & $26.7 \pm 4.3^{*}$ & $25.4 \pm 3.5$ \\
\hline Smoking habit (n, \%) & $89 *(58.6 \%)$ & $29(24.0 \%)$ \\
\hline Total cholesterol $($ mean $\pm \mathrm{SD}) \mathrm{mmol} / \mathrm{l}$ & $5.8 \pm 1.4^{*}$ & $5.3 \pm 1.4$ \\
\hline LDL-cholesterol (mean \pm SD) mmol/l & $3.9 \pm 1.2 *$ & $3.5 \pm 1.2$ \\
\hline HDL-cholesterol (mean \pm SD) mmol/l & $1.1 \pm 0.3$ & $1.1 \pm 0.4$ \\
\hline Triacylglycerols (mean \pm SD) mmol/l & $1.9 \pm 1.0^{*}$ & $1.5 \pm 0.7$ \\
\hline
\end{tabular}

CAD-coronary artery disease, LDL-low density lipoproteins, HDL-high density lipoproteins, BMI-body mass index, SD-standard deviation

* statistically significant data at $\mathrm{p}<0.05$

Almost $86 \%$ of the cases were recruited to the study in the state of acute coronary syndrome. Among patients there were $81 \%$ individuals who suffered from MI and $14.6 \%$ of them had more than one MI. Almost $60 \%$ of cases had critical stenosis and multivessel disease. More than $50 \%$ of patients had arterial hypertension.

\section{Analyses of polymorphism}

The genotype and allele frequencies of $677 \mathrm{C}>\mathrm{T}$ polymorphism of MTHFR gene in both groups were compatible to HWE (premature CAD p $=0.442, \chi^{2}=0.59$, control group $\left.\mathrm{p}=0.11, \chi^{2}=2.56\right)$. The term "carriers" were used for subjects with at least one T allele (subjects with genotypes CT+TT). The distributions of the MTHFR genotypes and alleles in the entire groups are shown in Table 2.

We found that $\mathrm{T}$ allele of MTHFR gene was more frequent in cases compared to controls ( $34 \%$ vs $28 \%$ ). It was also observed that homozygotes TT were twice as common in cases $(10 \%)$ than in controls $(5 \%)$ in reference to CC homozygotes $(\mathrm{OR}=2.71)$. This difference was on the borderline of statistical significance $(\mathrm{p}=0.083$ in multivariate analysis). The $\mathrm{T}$ allele carriers were also more common in the patients' group compared to controls ( $57 \%$ vs $51 \%$ ).

Tab. 2: Distribution of genotypes and alleles of MTHFR polymorphism and the results of comparison between CAD and control in entire groups and male subgroups

\begin{tabular}{|c|c|c|c|c|c|c|c|c|c|}
\hline \multirow{3}{*}{ Gene } & \multirow{3}{*}{$\begin{array}{l}\text { Genotype } \\
\text { / allele }\end{array}$} & \multicolumn{4}{|c|}{ Entire groups } & \multicolumn{4}{|c|}{ Male subgroups } \\
\hline & & \multicolumn{2}{|c|}{$\begin{array}{c}\text { Premature CAD } \\
n=152\end{array}$} & \multicolumn{2}{|c|}{$\begin{array}{l}\text { Control } \\
\mathrm{n}=121\end{array}$} & \multicolumn{2}{|c|}{$\begin{array}{c}\text { Premature CAD } \\
n=88\end{array}$} & \multicolumn{2}{|c|}{$\begin{array}{l}\text { Control } \\
\mathrm{n}=102\end{array}$} \\
\hline & & $\mathrm{n}$ & $\%$ & $\mathrm{n}$ & $\%$ & $\mathrm{n}$ & $\%$ & $\mathrm{n}$ & $\%$ \\
\hline \multirow{6}{*}{ MTHFR } & $\mathrm{CC}$ & 65 & 43 & 59 & 49 & 37 & 42 & 49 & 48 \\
\hline & $\mathrm{CT}$ & 72 & 47 & 56 & 46 & 42 & 48 & 48 & 47 \\
\hline & TT & 15 & 10 & 6 & 5 & 9 & 10 & 5 & 5 \\
\hline & $\mathrm{CT}+\mathrm{TT}$ & 87 & 57 & 62 & 51 & 51 & 58 & 53 & 52 \\
\hline & $\mathrm{C}$ & 202 & 66 & 174 & 72 & 116 & 66 & 146 & 72 \\
\hline & $\mathrm{T}$ & 102 & 34 & 68 & 28 & 60 & 34 & 58 & 28 \\
\hline \multicolumn{6}{|c|}{$\mathrm{T} / \mathrm{C} \mathrm{p}=0.171, \mathrm{OR}=1.2995 \% \mathrm{CI} 0.88-1.90^{*}$} & \multicolumn{4}{|c|}{$\mathrm{T} / \mathrm{C} \mathrm{p}=0.235, \mathrm{OR}=1.3095 \% \mathrm{CI} 0.82-2.06^{*}$} \\
\hline \multirow{2}{*}{\multicolumn{6}{|c|}{$\begin{array}{r}\mathrm{TT} / \mathrm{CC} \mathrm{p}=0.105, \mathrm{OR}=2.2795 \% \mathrm{CI} 0.76-7.06^{*} \\
\mathrm{p}=0.083, \mathrm{OR}=2.7195 \% \mathrm{CI} 0.87-8.43^{*} *\end{array}$}} & \multicolumn{4}{|c|}{$\mathrm{TT} / \mathrm{CC} \mathrm{p}=0.139, \mathrm{OR}=2.3895 \% \mathrm{CI} 0.65-9.04 *$} \\
\hline & & & & & & \multirow{2}{*}{\multicolumn{4}{|c|}{$\begin{aligned} \mathrm{p} & =0.264, \mathrm{OR}=2.0595 \% \text { CI } 0.58-7.28 * * \\
\mathrm{CT}+\mathrm{TT} / \mathrm{CC} \mathrm{p} & =0.408, \mathrm{OR}=1.2795 \% \text { CI } 0.69-2.36 * \mathrm{p} \\
& =0.310, \mathrm{OR}=1.4195 \% \text { CI } 0.72-2.77 * *\end{aligned}$}} \\
\hline \multicolumn{6}{|c|}{$\begin{array}{r}\mathrm{CT}+\mathrm{TT} / \mathrm{CC} \mathrm{p}=0.323, \mathrm{OR}=1.2795 \% \text { CI } 0.77-2.12 * \\
\mathrm{p}=0.099, \mathrm{OR}=1.5195 \% \text { CI } 0.92-2.45 * *\end{array}$} & & & & \\
\hline
\end{tabular}

CAD-coronary artery disease, OR-odds ratio, CI-confidence interval, * univariate analysis, ** multivariate analysis adjusted with levels of LDL-cholesterol, triacylglycerols and smoking 


\section{Relations between MTHFR polymorphism and traditional risk factors}

The main goal of our study was to analyze whether there are any interactions between $677 \mathrm{C}>\mathrm{T}$ polymorphism of the MTHFR gene and traditional risk factors which could increase the risk of premature CAD in the Polish patients from Upper Silesia region. There was observed increased risk of premature CAD in patients with $\mathrm{CT}$ genotype who simultaneously smoked when compared to non-smoking cases with wild-type genotype $(\mathrm{OR}=4.76)$. The risk was significantly increased in smoking subjects who were TT homozygotes $(\mathrm{OR}=24.62)$. The exact calculations $(6 \times 2$ approaches) of interactions between MTHFR genotypes and traditional risk factors are shown in Table 3. Moreover we demonstrated that the susceptibility to premature CAD was increased with the presence of at least one $T$ allele of MTHFR polymorphism and elevated level of LDL-chol. Individuals with TT genotype and elevated LDL-chol. level had significantly higher risk of CAD $(\mathrm{OR}=9.92)$ than individuals with normal LDL-chol. level and CC genotype. Similar result was found in case of TT homozygous subjects with contemporaneous presence of overweight (OR $=10.15$ ). These results may suggest that there are some additive relationships between MTHFR polymorphism and conventional risk factors for $\mathrm{CAD}$ in predicting the risk of the disease at younger age.

Tab. 3: Associations between genotypes of $677 \mathrm{C}>\mathrm{T}$ polymorphism of $M T H F R$ gene and traditional risk factors of CAD in study groups

\begin{tabular}{|c|c|c|c|c|}
\hline Genotype & Smoking & CAD & Control & OR $(95 \% \mathrm{CI}), \mathrm{p}$ \\
\hline $\mathrm{CC}$ & no & 21 & 47 & reference data \\
\hline $\mathrm{CC}$ & yes & 44 & 12 & $8.21(3.37-20.39), \mathrm{p}<0.001^{*}$ \\
\hline $\mathrm{CT}$ & no & 38 & 40 & $2.13(1.02-4.45), \mathrm{p}=0.028^{*}$ \\
\hline $\mathrm{CT}$ & yes & 34 & 16 & $4.76(2.02-11.32), \mathrm{p}<0.001 *$ \\
\hline $\mathrm{TT}$ & no & 4 & 5 & $\begin{array}{l}1.79(0.36-8.82), p=0.414 \\
\text { Fisher exact 1-tailed } p=0.321 \\
\text { Fisher exact 2-tailed } p=0.461\end{array}$ \\
\hline $\mathrm{TT}$ & yes & 11 & 1 & $\begin{array}{l}24.62(2.92-543.53), \mathrm{p}=0.00007^{*} \\
\text { Fisher exact } 1 \text {-tailed } \mathrm{p}=0.0001 \\
\text { Fisher exact 2-tailed } \mathrm{p}=0.0001\end{array}$ \\
\hline Genotype & $\mathrm{TC}>5.2 \mathrm{mmol} / 1$ & CAD & Control & OR $(95 \% \mathrm{CI}), \mathrm{p}$ \\
\hline $\mathrm{CC}$ & no & 24 & 30 & reference data \\
\hline $\mathrm{CC}$ & yes & 41 & 29 & $1.77(0.81-3.86), \mathrm{p}=0.118$ \\
\hline $\mathrm{CT}$ & no & 25 & 28 & $1.12(0.49-2.56), p=0.777$ \\
\hline $\mathrm{CT}$ & yes & 47 & 28 & $2.10(0.97-4.56), \mathrm{p}=0.04^{*}$ \\
\hline $\mathrm{TT}$ & no & 6 & 3 & $\begin{array}{l}2.50(0.48-14.33), p=0.216 \\
\text { Fisher exact 1-tailed } \mathrm{p}=0.199 \\
\text { Fisher exact 2-tailed } \mathrm{p}=0.289\end{array}$ \\
\hline TT & yes & 9 & 3 & $3.75(0.80-19.88), p=0.055$ \\
\hline Genotype & $\mathrm{LDL}>3.4 \mathrm{mmol} / 1$ & CAD & Control & OR $(95 \% \mathrm{CI}), \mathrm{p}$ \\
\hline $\mathrm{CC}$ & no & 24 & 34 & reference data \\
\hline $\mathrm{CC}$ & yes & 41 & 25 & $2.32(1.06-5.11), \mathrm{p}=0.021^{*}$ \\
\hline $\mathrm{CT}$ & no & 31 & 28 & $1.57(0.71-3.48), p=0.226$ \\
\hline CT & yes & 41 & 28 & $2.07(0.96-4.50), p=0.043^{*}$ \\
\hline TT & no & 8 & 5 & $2.27(0.57-9.26), \mathrm{p}=0.187$ \\
\hline $\mathrm{TT}$ & yes & 7 & 1 & $\begin{array}{l}9.92(1.09-228.80), p=0.0143^{*} \\
\text { Fisher exact } 1 \text {-tailed } p=0.017 \\
\text { Fisher exact } 2 \text {-tailed } p=0.021\end{array}$ \\
\hline
\end{tabular}




\begin{tabular}{|l|l|l|l|l|}
\hline \multicolumn{1}{|c|}{ Genotype } & \multicolumn{1}{|c|}{$\begin{array}{c}\text { Overweight } \\
\text { BMI }>25\end{array}$} & CAD & \multicolumn{1}{c|}{ Control } & \multicolumn{1}{c|}{ OR (95\% CI), $\mathrm{p}$} \\
\hline CC & no & 26 & 33 & reference data \\
\hline CC & yes & 39 & 26 & $1.90(0.88-4.15), \mathrm{p}=0.076$ \\
\hline CT & no & 30 & 26 & $1.46(0.66-3.27), \mathrm{p}=0.308$ \\
\hline CT & yes & 42 & 30 & $1.78(0.84-3.79), \mathrm{p}=0.104$ \\
\hline TT & no & 7 & 5 & $1.78(0.44-7.44), \mathrm{p}=0.366$ \\
\hline TT & yes & 8 & 1 & $\begin{array}{l}10.15(1.15-230.41), \mathrm{p}=0.012 * \\
\text { Fisher exact } 1 \text {-tailed } \mathrm{p}=0.014 \\
\text { Fisher exact } 2 \text {-tailed } \mathrm{p}=0.027\end{array}$ \\
\hline
\end{tabular}

CAD-coronary artery disease, TC - total cholesterol, LDL-low density lipoprotein, BMI-body mass index, OR-odds ratio, CI-confidence interval

* statistically significant data at $\mathrm{p}<0.05$

Additionally, we have made analysis of associations between MTHFR polymorphism and traditional risk factors and CAD in male subgroups due to gender disproportion. Table 4 shows the results of these calculations. We observed increased risk of premature CAD in male patients with CT genotype who simultaneously smoked compared to non-smoking cases with $\mathrm{CC}$ genotype $(\mathrm{OR}=5.57)$. The OR could not be defined in case of smoking male patients with TT genotype because of the lack of smoking control subject bearing TT genotype. We also found higher risk of premature $\mathrm{CAD}$ in male TT homozygous cases with overweight $(\mathrm{OR}=8.33)$.

Tab. 4: Associations between genotypes of $677 \mathrm{C}>\mathrm{T}$ polymorphism of $M T H F R$ gene and traditional risk factors of CAD in male subgroups

\begin{tabular}{|c|c|c|c|c|}
\hline Genotype & Smoking & CAD & Control & OR $(95 \% \mathrm{CI}), \mathrm{p}$ \\
\hline $\mathrm{CC}$ & no & 10 & 39 & reference data \\
\hline $\mathrm{CC}$ & yes & 27 & 10 & $10.53(3.48-33.10), \mathrm{p}<0.001^{*}$ \\
\hline CT & no & 22 & 34 & $2.52(0.97-6.68), p=0.036^{*}$ \\
\hline CT & yes & 20 & 14 & $5.57(1.90-16.74), p=0.0003^{*}$ \\
\hline TT & no & 0 & 5 & $\begin{array}{l}0.00(0.00-5.55), p=0.260 \\
\text { Fisher exact } 1 \text {-tailed } p=0.343 \\
\text { Fisher exact } 2 \text {-tailed } p=0.571\end{array}$ \\
\hline TT & yes & 9 & 0 & $\begin{array}{l}\text { undefined, } \mathrm{p}<0.0001 * \\
\text { Fisher exact } 1 \text {-tailed } \mathrm{p}<0.0001 \\
\text { Fisher exact } 2 \text {-tailed } \mathrm{p}<0.0001\end{array}$ \\
\hline Genotype & $\mathrm{TC}>5.2 \mathrm{mmol} / 1$ & CAD & Control & OR $(95 \% \mathrm{CI}), \mathrm{p}$ \\
\hline $\mathrm{CC}$ & no & 15 & 23 & reference data \\
\hline $\mathrm{CC}$ & yes & 22 & 26 & $1.30(0.50-3.37), p=0.554$ \\
\hline CT & no & 13 & 22 & $0.91(0.32-2.59), p=0.838$ \\
\hline $\mathrm{CT}$ & yes & 29 & 26 & $1.71(0.68-4.32), p=0.208$ \\
\hline TT & no & 5 & 2 & $\begin{array}{l}3.83(0.54-33.31), p=0.118 \\
\text { Fisher exact } 1 \text {-tailed } p=0.125 \\
\text { Fisher exact } 2 \text {-tailed } p=0.214\end{array}$ \\
\hline TT & yes & 4 & 3 & $\begin{array}{l}2.04(0.32-13.86), p=0.384 \\
\text { Fisher exact } 1 \text {-tailed } p=0.322 \\
\text { Fisher exact } 2 \text {-tailed } p=0.433\end{array}$ \\
\hline
\end{tabular}




\begin{tabular}{|c|c|c|c|c|}
\hline Genotype & $\mathrm{LDL}>3.4 \mathrm{mmol} / 1$ & CAD & Control & OR $(95 \% \mathrm{CI}), \mathrm{p}$ \\
\hline $\mathrm{CC}$ & no & 16 & 28 & reference data \\
\hline $\mathrm{CC}$ & yes & 21 & 21 & $1.75(0.68-4.55), p=0.202$ \\
\hline $\mathrm{CT}$ & no & 18 & 22 & $1.43(0.55-3.77), p=0.421$ \\
\hline $\mathrm{CT}$ & yes & 24 & 26 & $1.62(0.65-4.03), p=0.255$ \\
\hline TT & no & 6 & 4 & $\begin{array}{l}2.63(0.54-13.39), p=0.170 \\
\text { Fisher exact } 1 \text {-tailed } p=0.155 \\
\text { Fisher exact 2-tailed } p=0.285\end{array}$ \\
\hline $\mathrm{TT}$ & yes & 3 & 1 & $\begin{array}{l}5.25(0.42-143.19), p=0.130 \\
\text { Fisher exact } 1 \text {-tailed } p=0.164 \\
\text { Fisher exact 2-tailed } p=0.286\end{array}$ \\
\hline Genotype & $\begin{array}{c}\text { Overweight } \\
\text { BMI }>25\end{array}$ & CAD & Control & OR $(95 \% \mathrm{CI}), \mathrm{p}$ \\
\hline $\mathrm{CC}$ & no & 15 & 25 & reference data \\
\hline $\mathrm{CC}$ & yes & 22 & 24 & $1.53(0.59-3.97), p=0.335$ \\
\hline CT & no & 18 & 24 & $1.25(0.47-3.33), p=0.621$ \\
\hline $\mathrm{CT}$ & yes & 24 & 24 & $1.67(0.65-4.29), \mathrm{p}=0.240$ \\
\hline TT & no & 4 & 4 & $\begin{array}{l}1.67(0.29-9.68), p=0.509 \\
\text { Fisher exact 1-tailed } p=0.390 \\
\text { Fisher exact 2-tailed } p=0.695\end{array}$ \\
\hline TT & yes & 5 & 1 & $\begin{array}{l}8.33(0.79-207.83), p=0.035^{*} \\
\text { Fisher exact } 1 \text {-tailed } p=0.047 \\
\text { Fisher exact } 2 \text {-tailed } p=0.071\end{array}$ \\
\hline
\end{tabular}

CAD-coronary artery disease, TC - total cholesterol, LDL-low density lipoprotein, BMI-body mass index, OR-odds ratio, CI-confidence interval

* statistically significant data at $\mathrm{p}<0.05$

\section{Discussion}

The $677 \mathrm{C}>\mathrm{T}$ transition within MTHFR gene results in substitution of the alanine into valine in the mature reductase. This change causes increased thermolability and decreased enzymatic activity and in turn the elevation of the HCys level (4). The MTHFR polymorphism itself is related to CAD only in non-European populations (12-15) but not in European population (18). Atherosclerosis and CAD are multifactorial disorders. Clinical phenotype of these diseases may result of interactions between various genetic and environmental factors. Single gene analyses confirmed that associations between single genetic factors and $\mathrm{CAD}$ were rather weak. In our opinion, the analysis of possible interactions (synergistic, cumulative or antagonistic) between genetic and non-genetic factors may give more plausible results in the assessment of CAD risk in certain population.

Our study indicates that $\mathrm{T}$ allele of MTHFR $677 \mathrm{C}>\mathrm{T}$ polymorphism as well as TT homozygotes (in comparison to CC "wild"-type homozygotes) were more common in patients with premature CAD than in controls. We observed insignificant trend to higher frequency of T allele carriers in cases compared to controls. We found that presence of the TT genotype and one of the traditional risk factor for CAD, e.g. elevated level of LDL-chol., smoking or overweight, significantly increased the risk of the disease. Higher risk of premature CAD was observed in carriers of T allele who simultaneously smoke compared to non-smoking cases with wild-type genotype. The risk was especially high in smoking subjects bearing TT genotype $(\mathrm{OR}=24.62)$.

The MTHFR $677 \mathrm{C}>\mathrm{T}$ polymorphism and smoking habit were known to be the main predictors of total HCys levels (15). Previously, significant interaction between smoking and MTHFR $677 \mathrm{C}>\mathrm{T}$ polymorphism in the group of patients with lung cancer was found (16). Surprisingly, the authors demonstrated that CT and TT genotypes of MTHFR polymorphism in association with smoking conferred a decreased risk for lung cancer (16). In the large study exploring interactions between smoking and 34 SNPs of 24 genes in atherosclerosis, the $677 \mathrm{C}>\mathrm{T}$ polymorphism of MTHFR gene and smoking significantly interacted in four arteries (17). The authors observed that smokers bearing 
TT genotype are more likely to develop atherosclerosis than subjects with CT or CC genotypes.

In present study we also found that individuals with TT genotype and elevated LDL-chol. level had significantly higher risk of CAD $(\mathrm{OR}=9.92)$. In Croatian patients with carotid stenosis the carriers of the $\mathrm{T}$ allele had higher levels of LDL-chol. compared to CC homozygotes (18). Yilmaz et al. (19) demonstrated unfavorable effect of MTHFR polymorphism on serum lipid profile that leads to an elevated level of LDL-chol. in renal transplant recipients. The TT subjects in this study group had the highest LDL-chol. levels compared to CC or CT genotypes (19). Previously a positive correlation between plasma HCys level and cholesterol was observed in patients with hyperhomocysteinemia and in HepG2 cells (20). Since HCys stimulates the production and secretion of cholesterol and apoB100 in HepG2 cells (20), the MTHFR polymorphism related to elevated level of HCys may be indirectly associated to the production of cholesterol. Earlier, an interaction between LDL-chol. and HCys was suggested in the atherosclerotic processes (21).

We demonstrated also a relation between the MTHFR TT genotype and contemporaneous presence of overweight $(\mathrm{OR}=10.15)$. Recently, statistically higher levels of serum HCys were found in the overweight or obese individuals compared to subjects with normal BMI (22). There are conflicting results showing associations of MTHFR polymorphism and overweight or obesity (23-25). Some studies did not show such relations $(23,24)$. However, some of them showed higher BMI and waist-to-hip ratio in healthy postmenopausal women being carriers of the $677 \mathrm{C}>\mathrm{T}$ polymorphism compared to women with the CC genotype (25). On the other hand, in the study of Frelut et al. (26) the highest value of BMI was found in the obese adolescent girls having CC genotype compared to girls with CT or TT.

Our previous data demonstrated a role of MTHFR polymorphism in the cardio- and cerebrovascular diseases (27, 28). In the group of patients with CAD we observed that frequency of some double or triple combinations among polymorphisms of the MTHFR, IL- 6 and ICAMI genes, particularly for: $M T H F R+I C A M 1$ and $M T H F R+I C A M 1+I L-6$ patterns, differentiated patients from controls (27). The odds ratios were especially high in females subgroup (27). In the group of Polish children after stroke, MTHFR polymorphism seemed to be a risk factor for ischemic stroke, but in opposite to the results in CAD patients, in the male subgroup (28).

The present study has some limitations: the largest one is low number of analyzed subjects and lack of measurements of HCys and folate levels. Studies based on larger group of patients and controls are needed to confirm obtained results. Another limitation of our study is the fact that part of the included CAD patients were undergoing a treatment with cholesterol-lowering drugs which reflected in serum lipid levels. Important issue is also selective control group.
In conclusion, present work showed that the $677 \mathrm{C}>\mathrm{T}$ polymorphism within MTHFR gene is associated with the premature CAD only in a presence of given environmental risk factors, which is an interesting contribution to gene-environment interaction problem that may have clinical implications in the future.

Funding: projects: NN-2-014/05, NN-1-060/03 and KNW-1-037/08.

\section{Refferences}

1. Ross R. Atherosclerosis-an inflammatory disease. N Engl J Med 1999; 340: 115-126.

2. Talmud PJ. How to identify gene-environment interactions in a multifactorial disease: CHD as an example. Proc Nutr Soc. 2004; 63: 5-10.

3. Chaer RA, Billeh R, Massad MG. Genetics and gene manipulation therapy of premature coronary artery disease. Cardiology 2004; 101: 122-130.

4. Frosst P, Blom HJ, Milos R, et al. A candidate genetic risk factor for vascular disease: a common mutation in methylenetetrahydrofolate reductase. Nat Genet. 1995; 10: 111-113.

5. Clarke R, Daly L, Robinson K, Naughten E, Cahalane S, Fowler B et al. Hyperhomocysteinemia: an independent risk factor for vascular disease. N Engl J Med. 1991; 324: 1149-1155.

6. Biswas A, Ranjan R, Meena A, et al. Homocystine levels, polymorphisms and the risk of ischemic stroke in young Asian Indians. J Stroke Cerebrovasc Dis. 2009; 18: $103-110$.

7. den Heijer M, Blom HJ, Gerrits WB, et al. Is hyperhomocysteinaemia a risk factor for recurrent venous thrombosis? Lancet 1995; 345: 882-885.

8. Brattstrom L, Wilcken DE, Ohrvik J, Brudin L. Common methylenetetrahydrofolate reductase gene mutation leads to hyperhomocysteinemia but not to vascular disease: the result of a meta-analysis. Circulation 1998; 98: 2520-2526.

9. Alpert JS, Thygesen K, Myocardial infarction redefined - A consensus document of The Joint European Society of Cardiology/American College of Cardiology Committee for the Redefinition of Myocardial Infarction. Eur Heart J. 2000; 21 : 1502-1513.

10. Sarecka-Hujar B, Zak I, Krauze J. Interactions between rs5498 polymorphism in the ICAM1 gene and traditional risk factors influence susceptibility to coronary artery disease. Clin Exp Med. 2009; 9: 117-124.

11. Friedewald WT, Levy RI, Fredrickson DS. Estimation of the concentration of low-density lipoprotein cholesterol in plasma without the use of preparative centrifuge. Clin Chem. 1972; 18: 499-502.

12. Dhar S, Chatterjee S, Ray S, Dutta A, Sengupta B, Chakrabarti S. Polymorphisms of methylenetetrahydrofolate reductase gene as the genetic predispositions of coronary artery diseases in eastern India. J Cardiovasc Dis Res. 2010 Jul; 1: $152-157$.

13. Vijaya Lakshmi SV, Naushad SM, Rupasree Y, Seshagiri Rao D, Kutala VK. Interactions of $5^{\prime}$-UTR thymidylate synthase polymorphism with $677 \mathrm{C} \rightarrow \mathrm{T}$ methylene tetrahydrofolate reductase and $66 \mathrm{~A} \rightarrow \mathrm{G}$ methyltetrahydrofolate homocysteine methyl-transferase reductase polymorphisms determine susceptibility to coronary artery disease. J Atheroscler Thromb. 2011; 18: 56-64.

14. Tripathi R, Tewari S, Singh PK, Agarwal S. Association of homocysteine and methylene tetrahydrofolate reductase (MTHFR C677T) gene polymorphism with coronary artery disease (CAD) in the population of North India. Genet Mol Biol. 2010; 33: 224-228.

15. Bennouar N, Allami A, Azeddoug H, et al. Thermolabile Methylenetetrahydrofolate Reductase C677T Polymorphism and Homocysteine Are Risk Factors for Coronary Artery Disease in Moroccan Population. J Biomed Biotechnol. 2007; 2007(1): 80687. doi:10.1155/2007/80687

16 Liu CS, Tsai CW, Hsia TC, et al. Interaction of methylenetetrahydrofolate reductase genotype and smoking habit in Taiwanese lung cancer patients. Cancer Genomics Proteomics. 2009; 6: 325-329.

17. Sawabe M, Arai T, Araki A, et al. Smoking confers a MTHFR $677 \mathrm{C}>\mathrm{T}$ genotype-dependent risk for systemic atherosclerosis: results from a large number of elderly autopsy cases that died in a community-based general geriatric hospital. J Atheroscler Thromb. 2009; 16: 91-104.

18. Zuntar I, Antoljak N, Vrkić N, et al. Association of methylenetetrahydrofolate (MTHFR) and apolipoprotein E (apo E) genotypes with homocysteine, vitamin and lipid levels in carotid stenosis. Coll Antropol. 2006; 30: 871-878.

19. Yilmaz H, Agachan B, Isbir T, Akoglu E. Is there additional effect of MTHFR C677T mutation on lipid abnormalities in renal allograft recipients? Transplant Proc. 2003; 35: 1390-1392.

20. Karmin O, Lynn EG, Chung YH, Siow YL, Man RY, Choy PC. Homocysteine stimulates the production and secretion of cholesterol in hepatic cells. Biochim Biophys Acta. 1998; 1393: 317-324. 
21. McCully KS. Homocysteine and vascular disease. Nat Med. 1996; 2: 386-389.

22. Thawnashom K, Tungtrongchitr R, Petmitr S, et al. Methylenetetrahydrofolate reductase (MTHFR) polymorphism (C677T) in relation to homocysteine concentration in overweight and obese Thais. Southeast Asian J Trop Med Public Health 2005; 36: 459-466.

23. Settin AA, Algasham A, Dowaidar M, Ismail H. Methylene tetrahydrofolate reductase and angiotensin converting enzyme gene polymorphisms related to overweight/obesity among Saudi subjects from Qassim Region. Dis Markers. 2009; 27: 97-102

24. Liu X, Zhao LJ, Liu YJ, Xiong DH, Recker RR, Deng HW. The MTHFR gene polymorphism is associated with lean body mass but not fat body mass. Hum Genet. 2008; 123: 189-196.

25. Lambrinoudaki I, Kaparos G, Papadimitriou D, et al. Methylenetetrahydrofolate reductase $\mathrm{C} 677 \mathrm{~T}$ polymorphism is associated with central adiposity and increased androgenicity in healthy postmenopausal women. Eur J Endocrinol. 2008; 159: 233-241.

26. Frelut ML, Emery-Fillon N, Guilland JC, Dao HH, de Courcy GP. Alanine amino transferase concentrations are linked to folate intakes and methylenetetrahydrofolate reductase polymorphism in obese adolescent girls. J Pediatr Gastroenterol Nutr. 2006; 43: 234-239.

27. Sarecka-Hujar B, Zak I, Krauze J. Carrier-state of two or three polymorphic variants of MTHFR, IL- 6 and ICAM1 genes increases the risk of coronary artery disease. Kardiol Pol. 2008; 66: 1269-1277.

28. Zak I, Sarecka-Hujar B, Kopyta I, et al. The T allele of the $677 \mathrm{C}>\mathrm{T}$ polymorphism of methylenetetrahydrofolate reductase gene is associated with an increased risk of ischemic stroke in Polish children. J Child Neurol. 2009; 24: $1262-1267$

Received: 20/03/2012

Accepted in revised form: 10/10/2012

\section{Corresponding autor:}

Beata Sarecka-Hujar, PhD, Medical University of Silesia, Department of Applied Pharmacy, Kasztanowa Str 3, 41-200 Sosnowiec, Poland; e-mail: beatasarecka@poczta.onet.pl 